\title{
PSYCHE.
}

\section{CONTRIBUTION TO A LIST OF THE COLEOPTERA OF THE LOWER PENINSULA OF MICHIGAN.}

BY TYLER TOWNSEND, WASHINGTON, D. C.

The coleoptera, embracing i6r species, which appear in this list were all, with 9 designated exceptions, collected by the writer in the vicinity of Constantine, Saint Joseph county, Michigan, and form additions to the species given by Hubbard and Schwarz in their "Contribution to a list of the coleoptera of the lower peninsula of Michigan" (Proc. Amer. philos. soc., I878, v. I7, p. 643-666). The exceptions to the locality of Constantine referred to consist of 9 species which have been recorded elsewhere in the lower peninsula but are not included in the H. \& S. list; and the localities of these, whether general or special, are appended, the authorities for the same appearing after them in brackets.

For aid in the matter of determinations the writer is indebted to Dr. C. V. Riley, Mr. E. A. Schwarz of the Department of agriculture, and Mr. M. L. Linell of the National museum; also to Dr. G. H. Horn of Philadelphia, who kindly determined a portion of the species several years ago. A very large number of the coleoptera recorded by Hubbard and Schwarz as occurring in the lower peninsula of Michigan have been locally verified by being collected in Saint Joseph county, but are omitted from publication, as this simple additional list will prove much more useful. The species mentioned here, as well as all those collected in this locality, now form a part of the National museum collection.

In several genera, notably of staphylinidae, unnamed species have been collected, but those belonging to genera represented in the $\mathrm{H} . \& \mathrm{~S}$. list are not inserted, unnamed species being designated only in such genera as have not been recorded for the fauna.

\section{Cicindelidae.}

Cicindela 6-guttata F. var. patruela Dej. punctulata $\mathrm{F}$.

Carabidae.

Blethisa quadricollis Hald.

Pasimachus elongatus Lec.

Myas coracinus Say.

Diplochila impressicollis Dej.

Platynus tenuis Lec.

Galerita lecontei Dej.

Helluomorpha bicolor Harr. 
Brachynus minutus Harr. perplexus Dej. ? lateralis Dej.

Chlaenius ? laticollis Say. nemoralis Say. circumcinctus Say.

Brachylobus lithophilus Say.

\section{Dytiscidae.}

Agabus taeniolatus Harr. Dytiscus verticalis Say.

\section{HYDROPHILIDAE.}

Helophorus lacustris Lec. Hydrobius tessellatus Ziegl.

\section{Silphidae.}

Necrophorus guttula Mots.

Staphylinidae.

Homalota plana Gyll. festinans Er. elevata Fauv.

Callicerus n. sp.

Aleochara bimaculata Grav. Haploglossa n. sp.

Microglossa suturalis Mann. Oxypoda minuta Sachse.

Silusa n. sp.

Philonthus umbrinus Grav. varians Payk. longicornis Steph. sordidus Grav. microphthalmus Horn.

Stenus arculus Er.

Lathrobium anale Lec.

Boletobius exoletus Er.

Homalium humerosum Fauv.

\section{Coccinellidie.}

Hippodamia glacialis F. convergens Guér. Adalia frigida Schn.

Brachyacantha ursina F. (large form.)

Erotylidae.

Languria bicolor $\mathrm{F}$.

Cucujidae.

Laemophlaeus modestus Say. punctatus Lec. pusillus Sch.

\section{Dermestidae.}

Dermestes pulcher Lec. Trogoderma ornatum Say.

Histeridae.

Hister vernus Say.

Nitidulidae.

Carpophilus corticinus Er. Epuraea aestiva L. Rhizophagus bipunctatus Say.

\section{LATRIDIIDAE.}

Corticaria villosa Zimm.

Trogositidae.

Tenebrioides castanea Melsh. var. laticollis Horn.

Bactridium striolatum Reit.

Parnidae.

Dryops fastigiatus Say.

Macronychus glabratus Say. 
DAscyitidie.

Scirtes orbiculatus $\mathrm{F}$.

Cyphon variabilis Thunb. (yellow form.)

\section{Elateridae.}

Adelocera brevicornis Lec.

Cardiophorus gagates Er. tenebrosus Lec.

Elater manipularis Cand.

Melanotus macer Lec. paganus Cand.

Buprestidae.

Chalcophora liberta Germ. Mich. [Cook.]

Agrilus otiosus Say.

Brachys aeruginosa Gory.

\section{LAMPYRIDAE.}

Calopteron? terminale Say. Plateros canaliculatus Say. Telephorus marginellus Lec.

\section{Cileridae.}

Cymatodera brunnea Melsh. bicolor Say.

Chariessa pilosa Forst.

\section{Ptinidae.}

Amphicerus bicaudatus Say. Mich. [Cook.]

Dinoderus ? densus Lec.

Lyctus striatus Melsh.

\section{Cioidae.}

Cis chevrolatii Mellié.
Scarabaeidae.

Canthon laevis Drury.

Phanaeus carnifex L.

Geotrupes opacus Hald.

Trox suberosus F. erinaceus Lec. terrestris Say.

Lachnosterna prunina Lec.

Anomala binotata Gyll. undulata Melsh.

Chalepus trachypygus Burm.

Euphoria sepulchralis F.

Osmoderma eremicola Knoch.

Valgus canaliculatus F. squamiger Beauv.

\section{Cerambycidae.}

Phymatodes amoenus Say. dimidiatus Kirby.

Romaleum atomarium Drury.

Elaphidion mucronatum $\mathrm{F}$.

Plagionotus speciosus Say. Mich [Cook.]

Rhagium lineatum Oliv. Pine regions. [Cook.]

Strangalia famelica Newm.

luteicornis F.

hicolor Swed.

Typocerus lugubris Say. sinuatus Newm.

Leptura exigua Newm.

canadensis $\mathrm{F}$.

Monohammus titillator $\mathrm{F}$. Pine regions. [Cook.]

Goes pulchra Hald. pulverulenta Hald.

Hyperplatys aspersus Say.

Saperda candida F. Mich. [Cook.]

Tetraopes quinquemaculatus Hald. 
Chrysomelidae.

Donacia emarginata Kirby. cuprea Kirby.

flavipes Kirby.

Lema collaris Say.

Anomoea laticlavia Forst.

Coscinoptera dominicana $\mathrm{F}$.

Exema gibber Oliv.

Bassareus mammifer Newm. var. Mordella octopunctata F. luteipennis Melsh.

Cryptocephalus insertus Hald.

Pachybrachys othonus Say. var. carbonarius Hald.

luridus $F$.

id. (black form.)

Diachus auratus F.

Glyptoscelis pubescens F.

Paria 6-notata Say. (black form.) aterrima Oliv.

id. (black form.)

Lina lapponica L.

Adimonia externa Say.

Galeruca integra Lec.

Oedionychis scalaris Melsh. var.

Disonycha punctigera Lec.

pennsylvanica Ill.

Haltica chalybea Ill.

ignita Ill.

inaerata Lec.

Systena hudsonias Forst.

BruchidaE.

Spermophagus robiniae Sch.

Bruchus nigrinus Horn.

Tenebrionidae.

Xylopinus aenescens Lec.

Blapstinus metallicus F.

Uloma imberbis Lec.

\section{Cistelidae.}

Mycetochares bicolor Coup.

Melandryidae.

Tetratoma truncorum Lec.

Mordellidae.

Anthicidae.

Corphyra collaris Say.

Notoxus monodon F. (black form.)

Meloidae.

Nemognatha piezata F.

\section{RHIPIPHORIDAE.}

Rhipiphorus pectinatus $\mathrm{F}$.

RHYNCHITIDAE.

Rhynchites bicolor F.

Attelabidae.

Attelabus bipustulatus F.

OTIORHYNCHIDAE.

Otiorhynchus ovatus L.

Curculionidae.

Apion herculanum Smith.

Listronotus squamiger Say.

Lixus terminalis Lec.

Ceutorhynchus septentrionalis Gyll.

Baris umbilicata Lec.

Centrinus capillatus Lec. 
Calandridae.

Calandra remotepunctata Gyll. Cossonus platalea Say.

Scolytidae.

Pityophthorus pullus Zimm.
Coccotrypes jalappae Letz. Detroit. ['Schwarz.]

Tomicus calligraphus Germ. Pine regions. [Cook.]

Dendroctonus terebrans Oliv. Pine regions. [Cook.]

\section{A SHORT CHAPTER IN THE HISTORY OF THE CYNIPIDOUS GALL-FLIES.}

BY HOMER FRANKLIN BASSETT; WATERBURY, CT.

It was reasonable to suppose that when that most interesting field of research into the life history of the gall insects that relates to their agamic reproduction had been opened, some one or more of our young entomologists would have entered upon the investigations that were necessary, and long ago, have done for our American what the German and French entomologists have done for the European species.

The writer, who so long ago as I 864 , published the first clue to the solution of the mystery of agamic reproduction in the family of the cynipidae, has, unfortunately, grown old without finding the leisure to follow, very far, the fascinating field for discovery that then appeared before him.

I have, since then, done some fragmentary work in the way of describing new species, and some work that I do not yet despair of giving to the world in the shape of a monograph of the cyni- pidae, but the limited leisure I have had and the uncertainty of being able to follow to results, any investigations or observations that demanded attention at a definite time and place, has debarred me from following what I still think, one of the most interesting and important branches of entomological study.

I have gathered a few facts, however, and I beg to lay before the readers of Psyche an account of a discovery I made this last spring, partly in the hope that it may lead some one to go further in the same line,-but chiefly, because every discovery in science belongs to the world just as soon as its validity is established.

One of our most common gall insects here in Connecticut is Callirhytis futilis, O. S. The galls appear in early summer, in great numbers on the leaves of 2uercus alba. They are in the form of conical blotches, projecting from both surfaces of the leaf, but are more prom- 

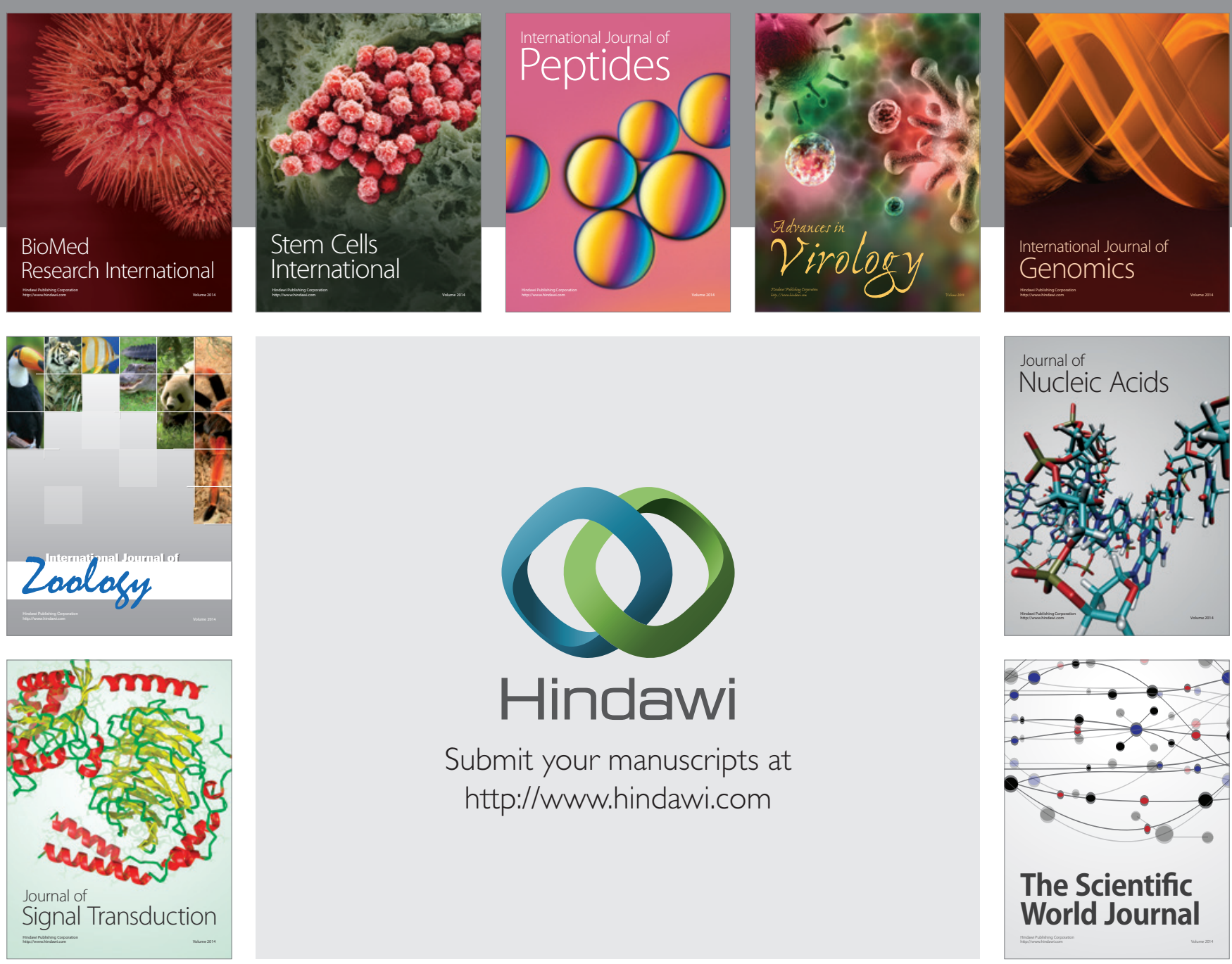

Submit your manuscripts at

http://www.hindawi.com
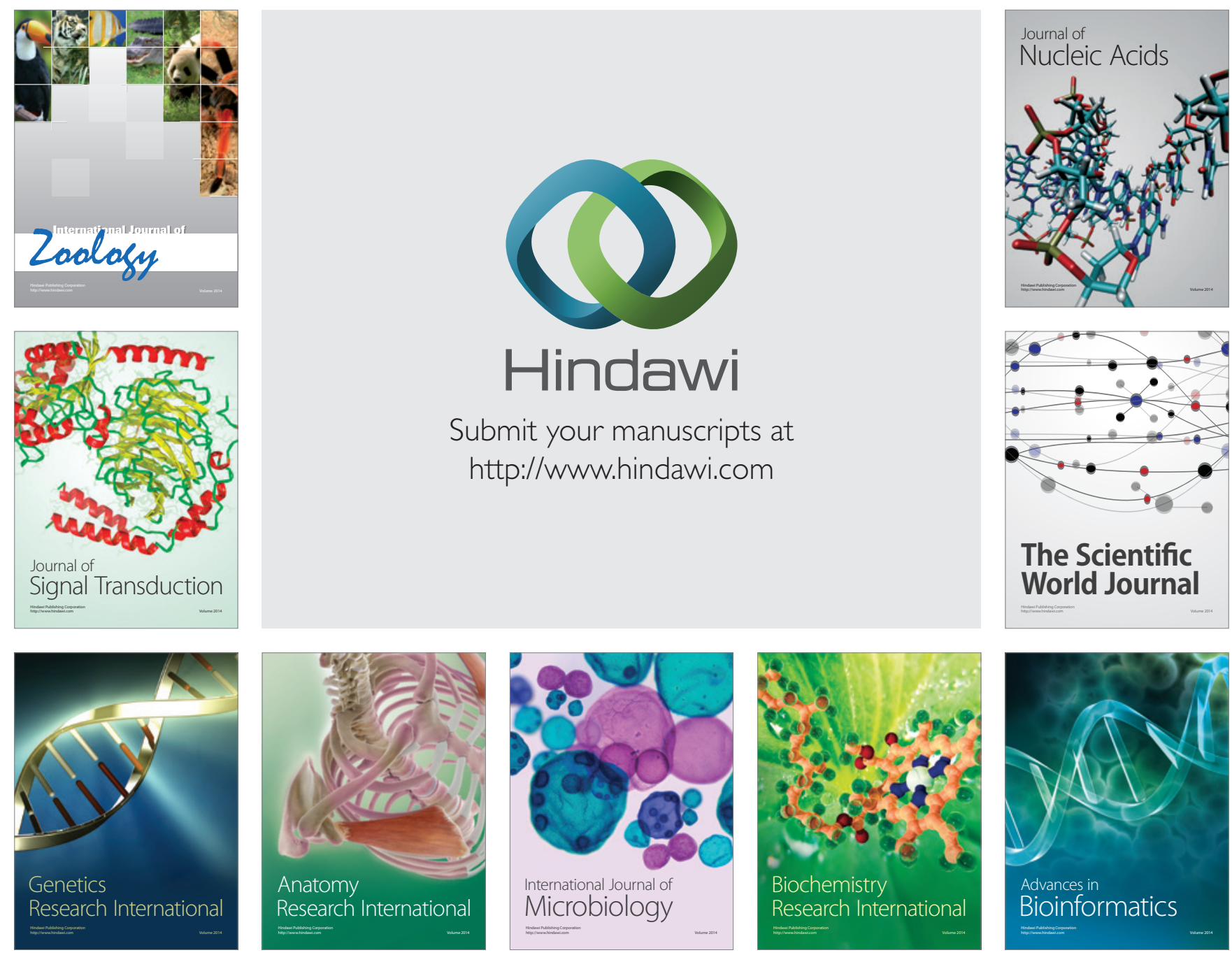

The Scientific World Journal
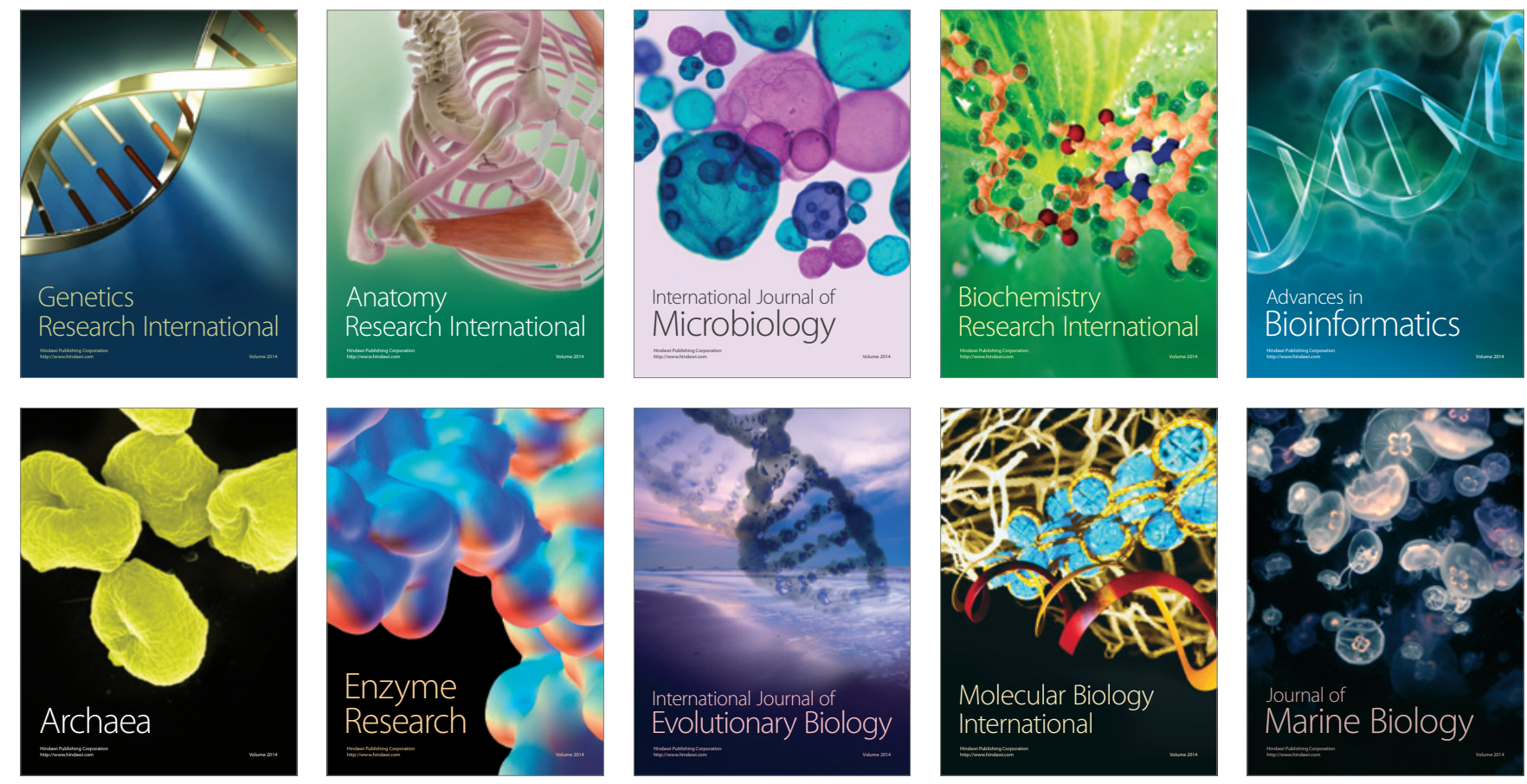